University of Nebraska - Lincoln

DigitalCommons@University of Nebraska - Lincoln

1975

\title{
Epidemiological Definition of the Cohort of Diseases Associated with Diabetes in Southwestern American Indians
}

Karl R. Reinhard DVM

Indian Health Service, Tucson AZ

Naomi I. Greenwalt

Indian Health Service, Tucson AZ

Follow this and additional works at: https://digitalcommons.unl.edu/publichealthresources

Reinhard, Karl R. DVM and Greenwalt, Naomi I., "Epidemiological Definition of the Cohort of Diseases Associated with Diabetes in Southwestern American Indians" (1975). Public Health Resources. 321. https://digitalcommons.unl.edu/publichealthresources/321

This Article is brought to you for free and open access by the Public Health Resources at DigitalCommons@University of Nebraska - Lincoln. It has been accepted for inclusion in Public Health Resources by an authorized administrator of DigitalCommons@University of Nebraska - Lincoln. 


\title{
Epidemiological Definition of the Cohort of Diseases Associated with Diabetes in Southwestern American Indians
}

\author{
Karl R. Reinhard, D.V.M., Ph.D., " and NaOmi I. Greenwalt $\nmid$
}

\begin{abstract}
A computerized health records system has facilitated an analysis of the correlated illness of a segment of population afflicted with a chronic disease. Taking the existence of clinical diabetes as a starting point, the total illness experience of 635 diabetics, as shown by clinic utilization data, has been compared with an age-sex-geographically matched control population.

The comparisons show that, overall, diabetics cause a caseload rate more than double that of nondiabetics. In 17 out of 22 broad health problem areas, the diagnosis caseload rates for diabetics varied from 1.3 to 3.7 times greater than the rate for matched, non-diabetic controls. Workload (physician visit and hospital days) comparisons showed even greater disparity.

Some of the comparisons confirm statistically the clinical impressions of diabetologists over the past years. Some of the findings are not reflections of orthodox clinical opinion. The results contribute to further elucidation of the natural history of this disease. They also indicate the need for the development of comprehensive clinical management programs for groups of interrelated conditions found in persons with chronic disease such as diabetes.
\end{abstract}

DuRING the past few years, a major proportion of our efforts have been devoted to the development of epidemiological information from a computerized health records data base, covering about 12,000 individuals, most of whom are Southwestern American Indians. We have worked towards the production of computerized data statements which may facilitate health services planning, surveillance, and evaluation. To these ends, we have given detailed attention to issues of health problem categorization, as well as units of problem

Presented to Epidemiology Section, 101st Annual Meeting of the American Public Health Association, November 7, 1973.

* Chief, Community Health Status Surveillance, Health Program Systems Center, Office of Research and Development, Indian Health Service, HSA, Public Health Service, DHEW, P.O. Box 11340, Tucson, Arizona 85734.

† Statistical Assistant, Community Health Status Surveillance. quantification which may provide direct input into program planning, budgeting, and evaluation. The conceptualization of this process has been published previously. ${ }^{2}$

One phase of our work is aimed at delineation of population groups of special pathogenetic interest, particularly cohorts of individuals suffering from salient syndromes which produce significant amounts of caseload and workload. Further, we have aimed at elucidation of major disease association groups, with the view of facilitating the planning, surveillance, and evaluation of health services by the definition of the larger caseload and workload of a population cohort sharing the same disease liabilities. In the population served in our area, diabetes is of extraordinary pathogenetic significance. Consequently we selected it as the salient condition for definition of the extent of associated disease problems, in a protoype study. 


\section{Methods}

First, in setting up the study, a computer program was developed to derive a roster, composed of all cases which had been given a diagnosis-either primary or secondaryof diabetes. This roster was carefully scrutinized to detect and remove decedents, non-Indians and non-Southwestern Indians. A total of 635 individuals were found to comprise the corrected diabetic roster.

Each of the diabetic individuals was matched as closely as possible, according to age, sex, and geographical location, with an individual having no record of diabetes, either clinical or asymptomatic. These persons formed the control population for statistical comparisons.

In addition, a problem-oriented medical summary and a complete, concise clinical encounter record was obtained from the computer data base for each diabetic individual, and each case was classed by severity, according to criteria used by Bennett and co-workers in their study of diabetes in other Southwestern American Indian people (Table 1). The diabetic and control groups had a total of 635 individuals each-248 male and 387 female. The distribution of both diabetics and controls by severity stage of the diabetics is given in Table 1.

In continuation of the study, we obtained tabulations of inpatient (patients and hospital days) and outpatient (patients and visits) utilization of clinical services. Tabulations were collected by an experimental health problem taxonomy previously described. ${ }^{2}$ This taxonomy has 25 major problem categories, and a total of 130 problem subcategories. Separate tabulations were made for the diabetics and controls, overall and by severity stage groupings. Separate tabulations were made according to primary diagnosis and all diagnoses. The former gives a more accurate count of utilization; the latter a more accurate picture of patterns of occurrence of disease conditions. It can be seen, according to the foregoing description of tabulation retrievals, that an immense amount of detailed data was obtained. In the space available for this presentation, we can discuss only salient features of the analyses of the data, dealing, for most part, with major health problem categories.

TABLE 1. Numerical Distribution of Diabetic (and Control) Population, Total and by Sex and Severity Stage of Diabetes

\begin{tabular}{lccccc}
\hline & Total & Stage 1 & Stage 2 & Stage 3 & Stage 4 \\
\hline Male & 248 & 5 & 145 & 84 & 14 \\
Female & 387 & 18 & 227 & 115 & 27 \\
Male and female & 635 & 23 & 372 & 199 & 41 \\
\hline
\end{tabular}

\section{Criteria for Classification of Diabetes Cases into Severity Stages}

Grade 1. Elevated blood sugar level. (Preferably this should be quantified by a glucose tolerance test). No other symptomatology.

Grade 1a. Patient is pregnant. Other criteria as in Grade 1.

Grade 2. Elevated blood sugar level. (Preferably, according to glucose tolerance test). "Classic" symptoms, such as polydipsia, polyuria, glucosuria, weight loss, and itching.

Grade 3. Criteria given in Grade 2, plus such symptoms and changes as persistent hypertension, peripheral vascular disease, peripheral neuropathy, retinopathy, arteriosclerotic changes including cerebrovascular disease, and proteinuria and other signs of developing nephropathy.

Grade 4. Symptoms and changes as in Grade 3, plus arteriosclerotic heart disease and/or established renal disease with elevated serum creatinine. 


\section{Study Group Characteristics}

Figure 1 shows the age-sex distribution of the diabetic and control population for this study. Considering the small size of many of the geographic subsets of the subject population, the matching was quite satisfactory. The age distribution of diabetics is almost bimodal, with a decreased prevalence between the modes of the 35to 39-year-old group and the nearly equal 50 to 59 -year-old group. The reason for this feature of the distribution of the disease is obscure. The preponderance of females in all groups is quite evident.

Figure 2 portrays graphically the difference in age distributions of the diabetic population and the general population served by our care system. Clinical diabetes is rare under 20 years of age, but rises rapidly in prevalence to the age of 40 , declining thereafter as age-group sizes decrease. The bimodality of age-distribution of the diabetics is also evident in this histogram.

Figure 3 shows the age distribution of severity stages 2,3 , and 4 of the diabetics. Stage 1 (asymptomatic diabetes) was not graphed, since we were sure it was inadequately represented in our sample. Only blanket survey of the entire population, by administration of a glucose tolerance test to each individual, would uncover all of the asymptomatic diabetics. According to the work of Bennett and others on like populations, the total number of grade 1 diabetics would most likely equal the total number of symptomatic diabetics. Naturally, uncomplicated symptomatic diabetes (Stage 2) occurs at earlier ages than Stages 3 and 4 , and increases rapidly in prevalence through the second, third, and fourth decades of life, declining thereafter as the advance severity stages increase in preva-

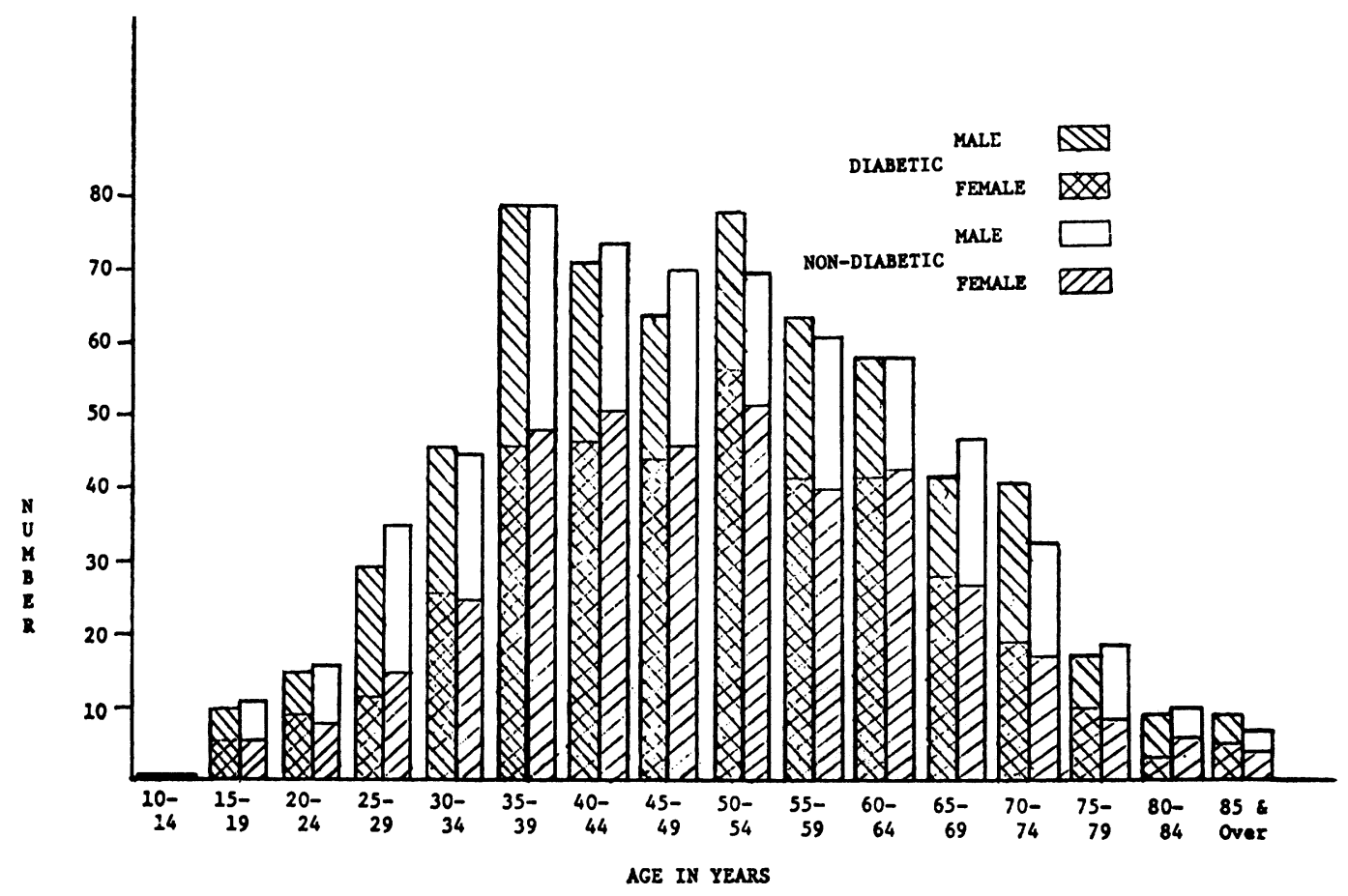

AGE-SEX DISTRIBUTIOX OF DIABETICS AND MTCHED NON-DLABETICS

Fig. 1. 


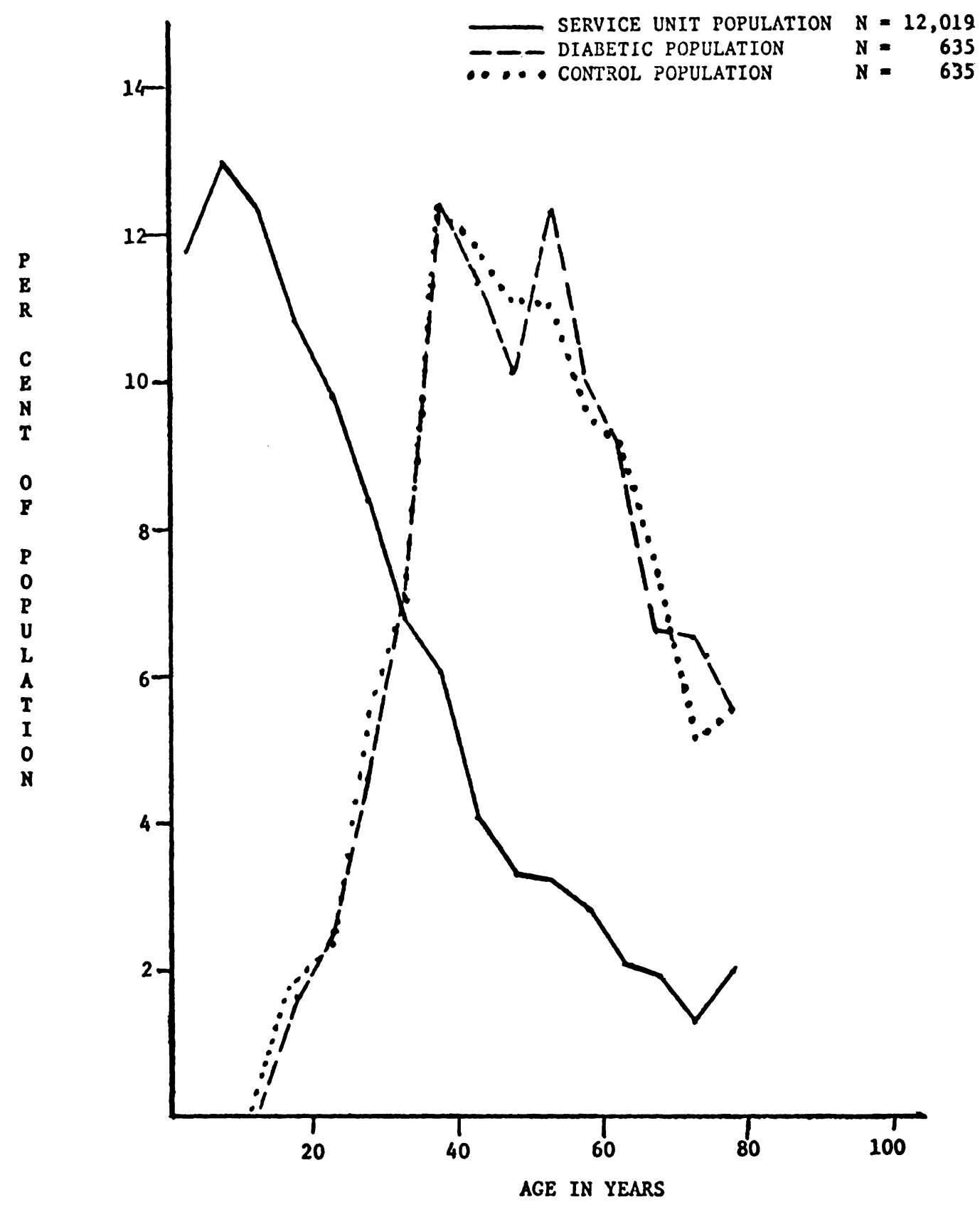

COMPARISON OF AGE DISTRIBUTION (\%) OF SELLS SERVICE UNIT, DIABETIC COHORT AND MATCHED NON-DIABETIC CONTROL SAMPLE.

FIG. 2. 


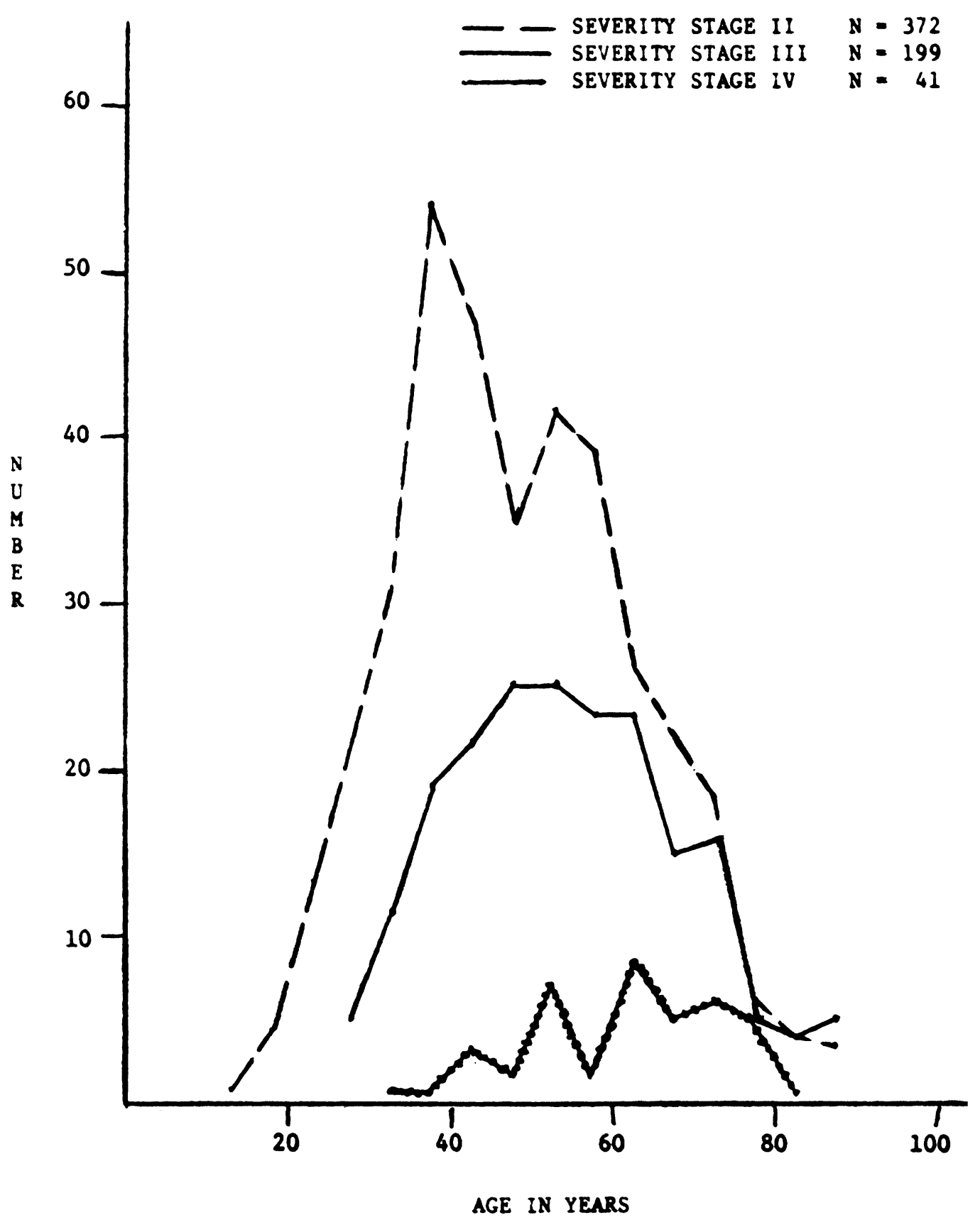

COMPARISON OF AGE DISTRIBUTION OF DIABETICS BY SEVERITY STAGE Fig. 3. 
lence. The rapid rise in prevalence of Severity Stage 3 between ages 30 and 40 is quite evident. Severity Stage 4 does not occur much before age 40 , and its prevalence does not reach a high level at any age. This severity group is the more subject to decrease by mortality, particularly because of the development of nephropathy.

Figure 4 shows the age and sex specific rates of occurrence of diabetes, based on the age-sex distribution of the persons on the diabetic register in calendar year 1972.

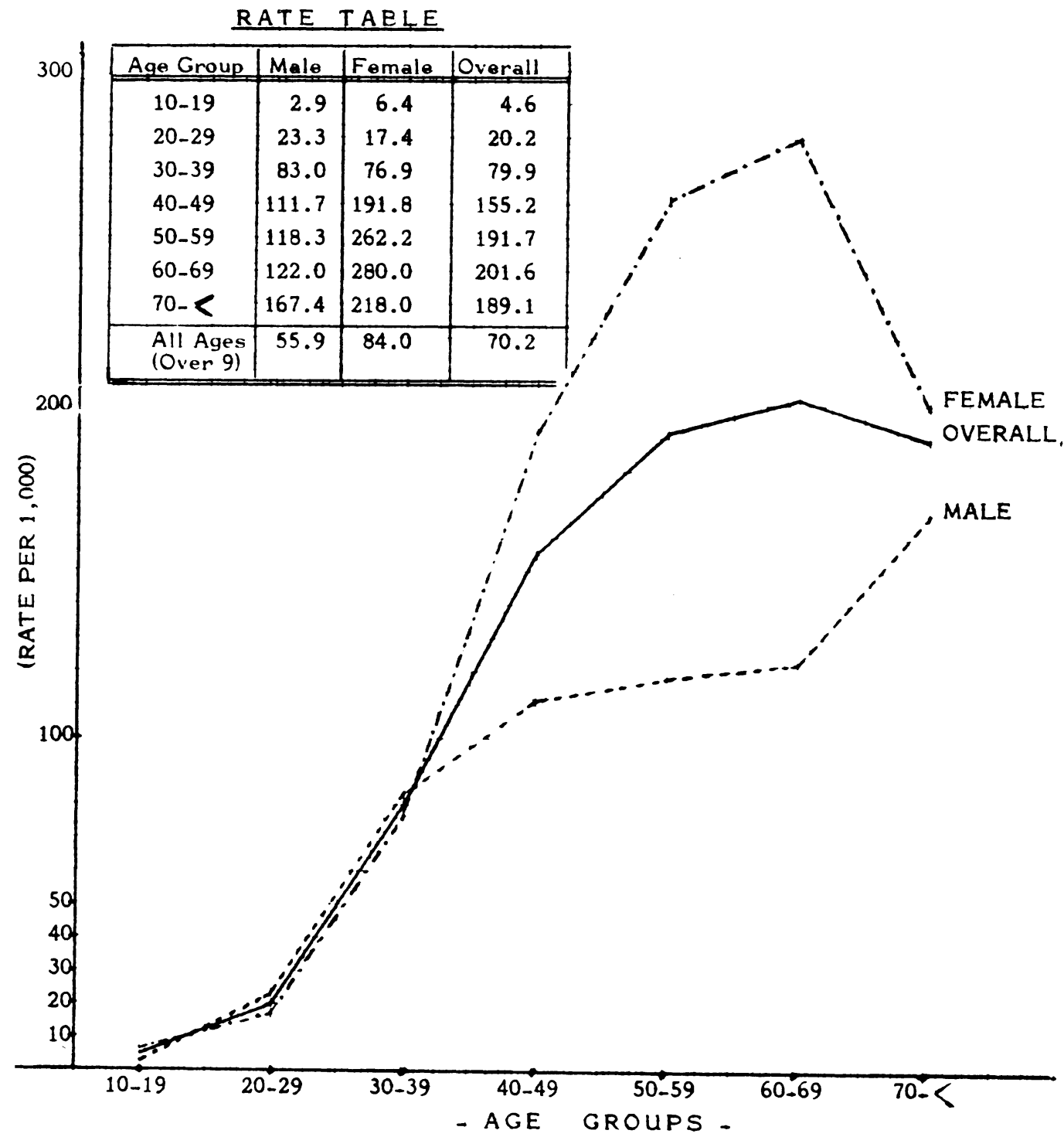

FIGURE 4: AGE-SEX SPECIFIC RATES FOR DIAGNOSED DIABETES, BASED ON DIABETIC REGISTER AND ESTIMATED BASE POPULATION. CALENDAR YEAR 1972. 
Notable in this histogram are the almost negligible difference in sex specific rates to the end of the fourth decade (30-39 years) of life, follwed by a rapid shift to large increments of rates of diabetes in females as compared with males. This differential shows some signs of reduction in the persons 70 years of age and greater.

\section{Outpatient Utilization Patterns}

The 635 diabetic individuals produced 1,906 clinical cases in calendar year 1972, causing a total of 4,900 outpatient visits. The matched control group produced 1,020 cases with a total of 1,915 outpatient visits. The rate of cases per 1,000 individuals per year, as shown in Table 2, amounted to 2,992 for the diabetics and 1,601 for the controls. Outpatient visits amounted to 7,693 per 1,000 population per year for the diabetics and 3,006 for the controls. The average number of visits per problem episode was 2.57 for the diabetics and 1.88 for the controls. In other analyses we found that, although nearly twice as many females as males were diabetics, the average number of visits of females per problem episode was slightly lower than that of the males.

To discern differences in health problem patterns, as indicated by utilization, outpatient cases and visits were tabulated and analyzed according to all diagnoses, ${ }^{*}$ not

" "Diagnoses" as used in these outpatient service analyses must be interpreted broadly. In most cases, a true medical diagnosis was made, but, in a substantial number of cases, visits were caused by need for preventive care, related to one or more specific or general health problems. primary diagnoses. Overall, more diagnoses were made per case with diabetics (average 1.23) than with the control group (average 1.16). The rate of diagnosis of differing kinds of disease, according to major health problem categories, is given in Table 3.

Overall, the diabetics accounted for nearly twice as many health problem episodes as the control group. Excluding consideration of the endocrine and metabolic disease category-in which we would naturally expect a very large differencein two of 22 categories (venereal disease and childbirth and complications), the diabetic problem episode rates were lower than those of the controls. In three categories of health problem areas (mental, injuries, and supplementary care), the rates for diabetics ranged from 1.16 to 1.21 times greater than the controls, which can be considered minor differences. In five categories, the difference between diabetic and control rates varied from 1.30 to 1.57 (other bacterial diseases, neurological and sensory, upper respiratory disease, lower respiratory disease and ill-defined conditions). These can be considered moderate differences. In the remaining 12 categories under consideration, major differences in problem experience were exhibited by rates for diabetics that ranged from 1.8 to 3.7 times those for the control group. These categories of major difference were gastroenteritis-diarrhea, tuberculosis, viral infections, other parasitic and infectious disease, neoplasms, blood dyscrasias (anemias), cardiovascular disease, digestive tract dis-

TABLE 2. Rates (per Thousand per Year) of Cases of Illness and Visits, and Case/Visit Ratios of Diabetics and Matched Control, CY 1972

\begin{tabular}{|c|c|c|c|c|c|c|}
\hline & \multicolumn{3}{|c|}{ Diabetics } & \multicolumn{3}{|c|}{ Controls } \\
\hline & Male & Female & Total & Male & Female & Total \\
\hline Outpatient case rate & 2,607 & 3,248 & 2,992 & 1,491 & 1,677 & 1,601 \\
\hline Outpatient visit rates & 7,020 & 8,148 & 7,693 & 2,986 & 3,029 & 3,007 \\
\hline Case/visit rates & 2.69 & 2.51 & 2.57 & 2.00 & 1.81 & 1.88 \\
\hline
\end{tabular}


TABLE 3. Rates of Diagnosis of Illness According to Major Health Problem Categories, among Diabetic and Control Populations, Outpatient Services, CY 1972 (All Diagnoses) *

\begin{tabular}{|c|c|c|c|c|c|c|c|c|c|}
\hline Problem Area & Class & M & $\mathrm{F}$ & $\mathrm{T}$ & Problem Area & Class & $\mathbf{M}$ & $\mathrm{F}$ & $\mathrm{T}$ \\
\hline Gastritis and diarrhea & $\begin{array}{l}\mathrm{D} \\
\mathrm{C}\end{array}$ & $\begin{array}{l}52 \\
28\end{array}$ & $\begin{array}{l}90 \\
52\end{array}$ & $\begin{array}{l}75 \\
42\end{array}$ & Neoplasms & $\stackrel{\mathrm{D}}{\mathrm{C}}$ & $\begin{array}{r}8 \\
12\end{array}$ & $\begin{array}{l}41 \\
10\end{array}$ & $\begin{array}{l}28 \\
11\end{array}$ \\
\hline Tuberculosis & $\begin{array}{l}\mathrm{D} \\
\mathrm{C}\end{array}$ & $\begin{array}{r}133 \\
48\end{array}$ & $\begin{array}{r}178 \\
72\end{array}$ & $\begin{array}{r}160 \\
63\end{array}$ & Endocrine-metabolic & $\stackrel{\mathrm{D}}{\mathrm{C}}$ & $\begin{array}{r}613 \\
4\end{array}$ & $\begin{array}{r}653 \\
41\end{array}$ & $\begin{array}{r}636 \\
27\end{array}$ \\
\hline Other bacterial diseases & $\begin{array}{l}\mathrm{D} \\
\mathrm{C}\end{array}$ & $\begin{array}{l}36 \\
32\end{array}$ & $\begin{array}{l}65 \\
41\end{array}$ & $\begin{array}{l}53 \\
38\end{array}$ & Blood dyscrasias & D & $\begin{array}{l}8 \\
4\end{array}$ & $\begin{array}{l}21 \\
13\end{array}$ & $\begin{array}{r}16 \\
9\end{array}$ \\
\hline Viral infections & $\begin{array}{l}\mathrm{D} \\
\mathrm{C}\end{array}$ & $\begin{array}{l}24 \\
12\end{array}$ & $\begin{array}{l}57 \\
26\end{array}$ & $\begin{array}{l}44 \\
20\end{array}$ & Mental disorders & $\stackrel{\mathrm{D}}{\mathrm{C}}$ & $\begin{array}{l}56 \\
65\end{array}$ & $\begin{array}{l}36 \\
21\end{array}$ & $\begin{array}{l}44 \\
38\end{array}$ \\
\hline Venereal diseases & $\begin{array}{l}\mathrm{D} \\
\mathrm{C}\end{array}$ & $\begin{array}{r}8 \\
24\end{array}$ & $\begin{array}{l}3 \\
5\end{array}$ & $\begin{array}{r}5 \\
13\end{array}$ & Neurological and sensory & $\begin{array}{l}\mathrm{C} \\
\mathrm{D}\end{array}$ & $\begin{array}{l}137 \\
198\end{array}$ & $\begin{array}{l}155 \\
201\end{array}$ & $\begin{array}{l}148 \\
199\end{array}$ \\
\hline $\begin{array}{l}\text { Other parasitic and } \\
\text { infectious diseases }\end{array}$ & $\stackrel{\mathrm{D}}{\mathrm{C}}$ & $\begin{array}{l}40 \\
28\end{array}$ & $\begin{array}{l}88 \\
18\end{array}$ & $\begin{array}{l}69 \\
22\end{array}$ & Cardiovascular & $\begin{array}{l}\mathrm{D} \\
\mathrm{C}\end{array}$ & $\begin{array}{l}270 \\
109\end{array}$ & $\begin{array}{l}286 \\
152\end{array}$ & $\begin{array}{l}280 \\
135\end{array}$ \\
\hline $\begin{array}{l}\text { Upper respiratory } \\
\text { diseases }\end{array}$ & D & $\begin{array}{l}157 \\
109\end{array}$ & $\begin{array}{l}148 \\
152\end{array}$ & $\begin{array}{l}212 \\
135\end{array}$ & Skin diseases & $\stackrel{\mathrm{D}}{\mathrm{C}}$ & $\begin{array}{r}113 \\
77\end{array}$ & $\begin{array}{r}163 \\
90\end{array}$ & $\begin{array}{r}143 \\
85\end{array}$ \\
\hline $\begin{array}{l}\text { Lower respiratory } \\
\text { diseases }\end{array}$ & $\begin{array}{l}\mathrm{D} \\
\mathrm{C}\end{array}$ & $\begin{array}{l}133 \\
117\end{array}$ & $\begin{array}{l}160 \\
114\end{array}$ & $\begin{array}{l}149 \\
115\end{array}$ & $\begin{array}{l}\text { Musculoskeletal } \\
\text { diseases }\end{array}$ & $\stackrel{\mathrm{D}}{\mathrm{C}}$ & $\begin{array}{r}157 \\
93\end{array}$ & $\begin{array}{l}230 \\
126\end{array}$ & $\begin{array}{l}201 \\
113\end{array}$ \\
\hline $\begin{array}{l}\text { Digestive tract } \\
\text { diseases }\end{array}$ & $\stackrel{\mathrm{D}}{\mathrm{C}}$ & $\begin{array}{r}105 \\
61\end{array}$ & $\begin{array}{r}142 \\
77\end{array}$ & $\begin{array}{r}127 \\
71\end{array}$ & Ill-defined conditions & $\begin{array}{l}\mathrm{D} \\
\mathrm{C}\end{array}$ & $\begin{array}{l}379 \\
246\end{array}$ & $\begin{array}{l}431 \\
284\end{array}$ & $\begin{array}{l}410 \\
269\end{array}$ \\
\hline $\begin{array}{l}\text { Urinary tract } \\
\text { diseases }\end{array}$ & $\stackrel{\mathrm{D}}{\mathrm{C}}$ & $\begin{array}{r}129 \\
44\end{array}$ & $\begin{array}{r}302 \\
77\end{array}$ & $\begin{array}{r}234 \\
64\end{array}$ & Injuries & $\begin{array}{l}\mathrm{D} \\
\mathrm{C}\end{array}$ & $\begin{array}{l}258 \\
258\end{array}$ & $\begin{array}{l}188 \\
134\end{array}$ & $\begin{array}{l}215 \\
182\end{array}$ \\
\hline $\begin{array}{l}\text { Genital tract } \\
\text { diseases }\end{array}$ & $\stackrel{\mathrm{D}}{\mathrm{C}}$ & $\begin{array}{r}36 \\
4\end{array}$ & $\begin{array}{r}103 \\
46\end{array}$ & $\begin{array}{l}77 \\
30\end{array}$ & Supplementary care & $\underset{\mathrm{C}}{\mathrm{D}}$ & $\begin{array}{l}230 \\
198\end{array}$ & $\begin{array}{l}320 \\
258\end{array}$ & $\begin{array}{l}284 \\
234\end{array}$ \\
\hline $\begin{array}{l}\text { Childbirth \& } \\
\text { complications }\end{array}$ & $\begin{array}{l}\mathrm{D} \\
\mathrm{C}\end{array}$ & $\begin{array}{l}0 \\
0\end{array}$ & $\begin{array}{l}31 \\
52\end{array}$ & $\begin{array}{l}19 \\
31\end{array}$ & All problem areas & $\begin{array}{l}\text { D 3, } \\
\text { C } 1 \text {, }\end{array}$ & , 143 & $\begin{array}{l}4,035 \\
1,963\end{array}$ & $\begin{array}{l}3,680 \\
1,854\end{array}$ \\
\hline
\end{tabular}

* Rates are expressed as number per 1,000 population/year; D = Diabetic, C = Control. "Diagnosis," as used in these outpatient service analyses, must be interpreted broadly. In most cases a true medical diagnosis was made, but, in a substantial number of cases, visits were caused by need for preventive care related to one or more specific or general health problems.

ease (other than gastroenteritis), urinary tract disease, genital disease, skin disease, and musculoskeletal disease.

\section{Inpatient Utilization Patterns}

During the period 1962 through 1972, a total of 867 admissions to the hospital were required by the diabetic individuals covered by this study, generating 12,594 hospital days, with an average length of stay of 14.5 days. The corresponding values for the control population were 529 admissions, 7,262 hospital days, and 13.7 days average length of stay. The rates per thousand of hospital admissions and hospital days, for the 11-year period, for males, females, and total, are given for both diabetics and controls in Table 4.

As with the outpatient data, the rates of occurrence of various diagnoses were calculated from tabulation of the distribution of all diagnoses, both primary and secondary, among the major health problem areas. An average of 1.9 diagnoses were rendered for each episode of hospitalization of a member of the diabetics and an average of 1.7 for each hospitalization of a member of the control group. This small difference may reflect the fact that the comparisons include hospitalizations of diabetics occurring prior to the time of onset of diabetes.

In Table 5, the rates of hospital diagnoses, both primary and secondary, are 
TABLE 4. Rates (per 1,000 Population) of Cases and Hospital Days and Average Lengths of Stay, 11-Year Period (CY 1962-72), for Diabetics and

Matched Control Population

\begin{tabular}{lrrrrrrrr}
\hline & \multicolumn{3}{c}{ Diabetics } & & \multicolumn{3}{c}{ Controls } \\
\cline { 2 - 3 } & Male & Female & Total & & Male & Female & Total \\
\hline Cases & 1,209 & 1,463 & 1,361 & & 789 & 864 & 831 \\
Hospital days & 18,277 & 20,503 & 19,773 & & 11,415 & 11,449 & 11,436 \\
Average length of stay & 15.5 & 14.0 & 14.5 & & 14.5 & 13.2 & 13.7 \\
\hline
\end{tabular}

compared among the major health problem areas. In only two categories (upper respiratory disease and childbirth and complications) did the diabetics show less experience than the controls. A slight increment of diagnoses for the diabetic group over the control levels were shown for other bacterial diseases and mental disorders. In the case of gastroenteritis-diarrhea, neoplasms, blood dyscrasias (anemias), neurological, and sensory diseases, lower respiratory diseases, injuries and supplementary

Table 5. Rates of Diagnosis of Illness According to Major Health Problem Categories, among Diabetic and Matched Control Populations, Inpatient Services, CY 1962-72 (All Diagnoses) *

\begin{tabular}{|c|c|c|c|c|c|c|c|c|c|}
\hline Problem Area & Class & $\mathrm{M}$ & $\mathrm{F}$ & $\mathrm{T}$ & Problem Area & Class & $\mathbf{M}$ & $\mathrm{F}$ & $\mathrm{T}$ \\
\hline Gastritis and diarrhea & D & $\begin{array}{l}32 \\
16\end{array}$ & $\begin{array}{l}75 \\
52\end{array}$ & $\begin{array}{l}58 \\
38\end{array}$ & Neoplasms & $\stackrel{\mathrm{D}}{\mathrm{C}}$ & $\begin{array}{l}12 \\
12\end{array}$ & $\begin{array}{l}36 \\
23\end{array}$ & $\begin{array}{l}27 \\
19\end{array}$ \\
\hline Tuberculosis & $\stackrel{\mathrm{D}}{\mathrm{C}}$ & $\begin{array}{r}105 \\
64\end{array}$ & $\begin{array}{l}88 \\
46\end{array}$ & $\begin{array}{l}94 \\
53\end{array}$ & Endocrine-metabolic & $\stackrel{\mathrm{D}}{\mathrm{C}}$ & $\begin{array}{r}512 \\
48\end{array}$ & $\begin{array}{r}539 \\
65\end{array}$ & $\begin{array}{r}528 \\
58\end{array}$ \\
\hline Other bacterial diseases & $\begin{array}{l}\mathrm{D} \\
\mathrm{C}\end{array}$ & $\begin{array}{l}0 \\
0\end{array}$ & $\begin{array}{r}10 \\
8\end{array}$ & $\begin{array}{l}6 \\
5\end{array}$ & Blood dyscrasias & $\begin{array}{l}\mathrm{D} \\
\mathrm{C}\end{array}$ & $\begin{array}{l}12 \\
12\end{array}$ & $\begin{array}{l}23 \\
13\end{array}$ & $\begin{array}{l}19 \\
13\end{array}$ \\
\hline Viral infections & $\underset{\mathrm{C}}{\mathrm{D}}$ & $\begin{array}{r}32 \\
4\end{array}$ & $\begin{array}{l}10 \\
10\end{array}$ & $\begin{array}{r}19 \\
8\end{array}$ & Mental disorders & $\stackrel{\mathrm{D}}{\mathrm{C}}$ & $\begin{array}{l}125 \\
109\end{array}$ & $\begin{array}{l}54 \\
46\end{array}$ & $\begin{array}{l}82 \\
71\end{array}$ \\
\hline Venereal diseases & $\stackrel{\mathrm{D}}{\mathrm{C}}$ & $\begin{array}{l}44 \\
16\end{array}$ & $\begin{array}{l}18 \\
16\end{array}$ & $\begin{array}{l}28 \\
16\end{array}$ & Neurological and sensory & $\begin{array}{l}\mathrm{D} \\
\mathrm{C}\end{array}$ & $\begin{array}{l}137 \\
117\end{array}$ & $\begin{array}{r}124 \\
57\end{array}$ & $\begin{array}{r}129 \\
80\end{array}$ \\
\hline $\begin{array}{l}\text { Other parasitic and } \\
\text { infectious diseases }\end{array}$ & $\begin{array}{l}\mathrm{D} \\
\mathrm{C}\end{array}$ & $\begin{array}{l}12 \\
16\end{array}$ & $\begin{array}{r}23 \\
8\end{array}$ & $\begin{array}{l}19 \\
11\end{array}$ & $\begin{array}{l}\text { Cardiovascular } \\
\text { diseases }\end{array}$ & $\begin{array}{l}\mathrm{D} \\
\mathrm{C}\end{array}$ & $\begin{array}{l}214 \\
109\end{array}$ & $\begin{array}{l}204 \\
103\end{array}$ & $\begin{array}{l}207 \\
105\end{array}$ \\
\hline $\begin{array}{l}\text { Upper respiratory } \\
\text { diseases }\end{array}$ & $\begin{array}{l}\mathrm{D} \\
\mathrm{C}\end{array}$ & $\begin{array}{r}20 \\
8\end{array}$ & $\begin{array}{l}23 \\
34\end{array}$ & $\begin{array}{l}22 \\
24\end{array}$ & Skin diseases & $\stackrel{\mathrm{D}}{\mathrm{C}}$ & $\begin{array}{r}125 \\
53\end{array}$ & $\begin{array}{r}132 \\
36\end{array}$ & $\begin{array}{r}129 \\
42\end{array}$ \\
\hline $\begin{array}{l}\text { Lower respiratory } \\
\text { diseases }\end{array}$ & $\stackrel{\mathrm{D}}{\mathrm{C}}$ & $\begin{array}{r}117 \\
89\end{array}$ & $\begin{array}{r}114 \\
85\end{array}$ & $\begin{array}{r}115 \\
86\end{array}$ & $\begin{array}{l}\text { Musculoskeletal } \\
\text { diseases }\end{array}$ & $\stackrel{\mathrm{D}}{\mathrm{C}}$ & $\begin{array}{l}77 \\
52\end{array}$ & $\begin{array}{l}85 \\
26\end{array}$ & $\begin{array}{l}82 \\
36\end{array}$ \\
\hline $\begin{array}{l}\text { Digestive tract } \\
\text { diseases }\end{array}$ & $\begin{array}{l}\mathrm{D} \\
\mathrm{C}\end{array}$ & $\begin{array}{r}165 \\
73\end{array}$ & $\begin{array}{l}219 \\
163\end{array}$ & $\begin{array}{l}198 \\
127\end{array}$ & Ill-defined conditions & $\stackrel{\mathrm{D}}{\mathrm{C}}$ & $\begin{array}{l}97 \\
73\end{array}$ & $\begin{array}{r}103 \\
46\end{array}$ & $\begin{array}{r}101 \\
57\end{array}$ \\
\hline $\begin{array}{l}\text { Urinary tract } \\
\text { diseases }\end{array}$ & $\begin{array}{l}\mathrm{D} \\
\mathrm{C}\end{array}$ & $\begin{array}{l}96 \\
65\end{array}$ & $\begin{array}{r}168 \\
85\end{array}$ & $\begin{array}{r}140 \\
77\end{array}$ & Injuries & $\begin{array}{l}\mathrm{D} \\
\mathrm{C}\end{array}$ & $\begin{array}{l}225 \\
250\end{array}$ & $\begin{array}{l}201 \\
116\end{array}$ & $\begin{array}{l}210 \\
168\end{array}$ \\
\hline $\begin{array}{l}\text { Genital tract } \\
\text { diseases }\end{array}$ & $\begin{array}{l}\mathrm{D} \\
\mathrm{C}\end{array}$ & $\begin{array}{l}69 \\
24\end{array}$ & $\begin{array}{r}111 \\
52\end{array}$ & $\begin{array}{l}94 \\
41\end{array}$ & Supplementary care & $\stackrel{\mathrm{D}}{\mathrm{C}}$ & $\begin{array}{r}125 \\
65\end{array}$ & $\begin{array}{l}152 \\
111\end{array}$ & $\begin{array}{r}141 \\
93\end{array}$ \\
\hline $\begin{array}{l}\text { Childbirth \& } \\
\text { complications }\end{array}$ & $\begin{array}{l}\mathrm{D} \\
\mathrm{C}\end{array}$ & $\begin{array}{l}0 \\
0\end{array}$ & $\begin{array}{l}186 \\
227\end{array}$ & $\begin{array}{l}113 \\
138\end{array}$ & All problem areas & $\begin{array}{l}\text { C } 1, \\
\text { D } 2\end{array}$ & $\begin{array}{l}1,274 \\
2,362\end{array}$ & $\begin{array}{r}1,445 \\
2,701\end{array}$ & $\begin{array}{l}1,375 \\
2,563\end{array}$ \\
\hline
\end{tabular}

* Rates are expressed in number per 1,000 for the pe:iod 1962-72; D = Diabetic, C = Control. Congenital anomalies not included in array. 
care, a moderate increment of diagnoses, in reference to the control population, occurred among the diabetics. Major differences between the level of diagnoses for controls and diabetes occurred in the categories tuberculosis, viral infection, venereal, other parasitic and infectious, cardiovascular, digestive tract, urinary tract, skin and musculoskeletal diseases, as well as illdefined conditions. The large difference in diagnosis of endocrine and metabolic diseases is a natural result of the population group selections.

\section{Mortality}

The scope, precision, and accuracy of retrospective mortality data currently available for this study does not match the quality of the clinical utilization data. Basically, the problem is generated by the fact that a large proportion of deaths among our "service" population occur in places or circumstances outside of the jurisdiction of our health service facilities. The state office of vital statistics is highly cooperative and attempts to provide us detailed information about the death of each decedent identified as an American Indian. But the problem arises in the sure identification of decedents as Indians, since many have Spanish surnames and registrars may have difficulty ascertaining the race of the individual as well as the tribal affiliation of Amerind people. Complicating these facts are the well known issues of the definition of underlying cause or contributory causes of death. Chronic underlying disease conditions are often missed, particularly in accidental deaths. Consequently, we are unable, at the moment, to ascertain either the numbers or rates of deaths among persons with clinically recognized diabetes as compared with the general population or a selected control population. This will be an important part of the prospective study now initiated. Some facts of potential significance have been derived from available sets of data which, unfortunately, are only partly related chronologically. These are the average age at death of known diabetics (age 35 and over), whose deaths occurred between 1961 and 1972, was 64.2 years (no deaths occurred in this group under 35 years of age), and the average age at death, of persons over 35 years of age, excluding deaths in which diabetes was indicated as the underlying cause, was 68.2 years in calendar years 1970 and 1971. While we believe this comparison does indicate a trend towards death at an earlier age in diabetics of this population as compared with nondiabetics, only a prospective study or a fortuitous acquisition of reliable retrospective data will settle the issue.

\section{Other Considerations}

From the foregoing considerations of the differing health problems of diabetics and persons not showing evidence of diabetes, it is obvious that these groups present differing needs for health services, involving a wide spectrum of health problems. Table 6 shows the comparative ranking of the "first 10" out of 23 general problem areas, according to caseloads and workloads caused by diabetic and nondiabetic individuals. The disparity is evident generally and striking in some instances. When one compares outpatient services utilization levels of the diabetic population with those of the whole service population, the striking facts emerge that during CY 1972 the recognized diabetics formed about 5.3 per cent of the population, but accounted for 11.1 per cent of the diagnoses rendered and caused 14.1 per cent of the clinic visit workload. On these bases alone, it may be desirable to plan a program of comprehensive health care specifically for diabetics, when they provide so large a proportion of the clinical workload.

The change in service needs of the various Severity Stages, as expressed in prob- 
TABLE 6. Comparison of Ranking of Health Problems, Diabetic vs. Control Population, Cases and Visits, All Diagnosis, CY 72.

\begin{tabular}{|c|c|c|c|c|c|c|c|c|c|}
\hline & \multicolumn{2}{|c|}{$\begin{array}{r}\text { Ranking by } \\
\text { Case Rates }\end{array}$} & \multicolumn{2}{|c|}{$\begin{array}{c}\text { Ranking by } \\
\text { Visit Rates }\end{array}$} & & \multicolumn{2}{|c|}{$\begin{array}{r}\text { Ranking by } \\
\text { Case Rates }\end{array}$} & \multicolumn{2}{|c|}{$\begin{array}{l}\text { Ranking by } \\
\text { Visit Rates }\end{array}$} \\
\hline & $\mathrm{D}$ & $\mathrm{C}$ & $\mathrm{D}$ & $\mathrm{C}$ & & $\mathrm{D}$ & C & $\mathrm{D}$ & C \\
\hline $\begin{array}{l}\text { Gastroenteritis-diarrheal } \\
\text { disease }\end{array}$ & & & & & Upper respiratory diseases & 7 & 5 & & 8 \\
\hline Tuberculosis & 9 & & 8 & & Influenza-pneumonia & & 6 & & 7 \\
\hline Other bacterial infections & & & & & Digestive tract diseases & & 10 & & \\
\hline Viral diseases & & & & & Urinary tract diseases & 5 & & 5 & \\
\hline Venereal diseases & & & & & Genital tract diseases & & & & \\
\hline $\begin{array}{l}\text { Other parasitic \& } \\
\text { infectious diseases }\end{array}$ & & & & & Childbirth \& complications & & & & 10 \\
\hline Neoplasms & & & & & Skin diseases & & 9 & 9 & 9 \\
\hline $\begin{array}{l}\text { Endocrine \& metabolic } \\
\text { diseases }\end{array}$ & 1 & & 1 & & Musculoskeletal diseases & 8 & 7 & 4 & 5 \\
\hline Blood dyscrasias & & & & & Ill-defined conditions & 2 & 1 & 2 & 1 \\
\hline Mental diseases & & & & & Injuries & 6 & 3 & 7 & 4 \\
\hline Nervous \& sensory diseases & 10 & 4 & 10 & 6 & Supplementary care & 3 & 2 & 6 & 3 \\
\hline Cardiovascular diseases & 4 & 8 & 3 & 2 & & & & & \\
\hline
\end{tabular}

Ranking is based on weight of numbers of diagnoses or visits per problem area (outpatient data); $\mathrm{D}=$ Diabetics, $\mathrm{C}=$ Control.

lem-specific rates of utilization, is illustrated by the data in Table 7 . These data are selected from a longer table of analyses of outpatient services for CY 1972. Note that rates for Severity Stage 1 are not included. The reason for this-the disproportionately low representation of this group-has been discussed previously. A scan of Table 8 reveals that the rates of clinic utilization for other problems correlated with the existence of diabetes do vary among severity stages of the disease. The trend, generally, in the examples shown, is an increase in prevalence of the disease in question between Stages 2 and 4 as compared with control group rates. But in the case of gastroenteritis, cardiovascular disease and digestive tract disease, the control population for the Stage 4 diabetics had larger utilization rates. Several epidemiological and demographic factors probably interact in producing these differences from the general trends. One is the fact that Grade 4 is also an advanced age group, and differential mortality may have affected the relative size of the two groups. Another factor may be the small size of these groups, making the mean rates greatly susceptible to skew caused by excessive utilization by one individual of the group.

In the foregoing, we have looked at data in relation to relatively large health problem areas. Before closing, it is desirable to look at the difference in utilization by the diabetics and the control groups in relation to more circumscribed or specific problem areas. Table 8 presents data on selected health problem categories, within which significant differences in case rates occurred between the diabetics and controls in outpatient or inpatient services utilization, or both. A number of problem categories in which the differences were moderate, minor, or equivocal are not shown 
TABLE 7. Variation in Levels of Health Problems with Changes in Severity of Diabetes, as Compared with Control Population Diagnosis Rates/1,000/Population/Annum

Outpatient, All Diagnosis CY 72.

\begin{tabular}{|c|c|c|c|c|c|c|c|c|c|}
\hline \multirow{3}{*}{ Gastroenteritis-diarrhea } & \multirow{2}{*}{$\begin{array}{l}\text { Population } \\
\text { Class }\end{array}$} & \multicolumn{8}{|c|}{ Severity Stage } \\
\hline & & & All & & 2 & & & & 4 \\
\hline & $\begin{array}{l}\text { D } \\
\text { C } \\
\text { D/C }\end{array}$ & $\begin{array}{l}75 \\
42\end{array}$ & 1.8 & $\begin{array}{l}70 \\
38\end{array}$ & 1.8 & $\begin{array}{l}85 \\
35\end{array}$ & 2.4 & $\begin{array}{r}73 \\
122\end{array}$ & 0.6 \\
\hline Tuberculosis (all components) & $\begin{array}{l}\mathrm{D} \\
\mathrm{C} \\
\mathrm{D} / \mathrm{C}\end{array}$ & $\begin{array}{r}160 \\
63\end{array}$ & 2.5 & $\begin{array}{r}135 \\
54\end{array}$ & 2.5 & $\begin{array}{r}210 \\
90\end{array}$ & 2.3 & $\begin{array}{r}195 \\
49\end{array}$ & 4.0 \\
\hline $\begin{array}{c}\text { Bacterial diseases } \\
\text { (not } \mathrm{TB}, \mathrm{VD})\end{array}$ & $\begin{array}{l}\mathrm{D} \\
\mathrm{C} \\
\mathrm{D} / \mathrm{C}\end{array}$ & $\begin{array}{l}53 \\
38\end{array}$ & 1.4 & $\begin{array}{l}57 \\
32\end{array}$ & 1.8 & $\begin{array}{l}46 \\
35\end{array}$ & 1.3 & $\begin{array}{l}73 \\
24\end{array}$ & 3.0 \\
\hline Mental disorders & $\begin{array}{l}\mathrm{D} \\
\mathrm{C} \\
\mathrm{D} / \mathrm{C}\end{array}$ & $\begin{array}{l}44 \\
38\end{array}$ & 1.2 & $\begin{array}{l}35 \\
35\end{array}$ & 1.0 & $\begin{array}{l}65 \\
45\end{array}$ & 1.4 & $\begin{array}{l}49 \\
24\end{array}$ & 2.0 \\
\hline Neurologeal sensory diseases & $\begin{array}{l}\mathrm{D} \\
\mathrm{C} \\
\mathrm{D} / \mathrm{C}\end{array}$ & $\begin{array}{l}199 \\
148\end{array}$ & 1.3 & $\begin{array}{l}140 \\
156\end{array}$ & 0.9 & $\begin{array}{l}310 \\
150\end{array}$ & 2.1 & $\begin{array}{l}268 \\
146\end{array}$ & 1.8 \\
\hline Cardiovascular diseases & $\begin{array}{l}\mathrm{D} \\
\mathrm{C} \\
\mathrm{D} / \mathrm{C}\end{array}$ & $\begin{array}{r}280 \\
96\end{array}$ & 2.9 & $\begin{array}{r}126 \\
83\end{array}$ & 1.5 & $\begin{array}{l}530 \\
105\end{array}$ & 5.0 & $\begin{array}{l}488 \\
732\end{array}$ & 0.7 \\
\hline Digestive tract diseases & $\begin{array}{l}\text { D } \\
\text { C } \\
\text { D/C }\end{array}$ & $\begin{array}{r}127 \\
71\end{array}$ & 1.8 & $\begin{array}{r}129 \\
54\end{array}$ & 2.4 & $\begin{array}{r}140 \\
80\end{array}$ & 1.8 & $\begin{array}{l}122 \\
195\end{array}$ & 0.6 \\
\hline Urinary tract diseases & $\begin{array}{l}\mathrm{D} \\
\mathrm{C} \\
\mathrm{D} / \mathrm{C}\end{array}$ & $\begin{array}{r}234 \\
64\end{array}$ & 3.7 & $\begin{array}{r}188 \\
75\end{array}$ & 2.5 & $\begin{array}{r}325 \\
40\end{array}$ & 8.1 & $\begin{array}{r}244 \\
49\end{array}$ & 5.0 \\
\hline Skin diseases & $\begin{array}{l}\mathrm{D} \\
\mathrm{C} \\
\mathrm{D} / \mathrm{C}\end{array}$ & $\begin{array}{r}143 \\
85\end{array}$ & 1.7 & $\begin{array}{l}97 \\
83\end{array}$ & 1.2 & $\begin{array}{r}235 \\
95\end{array}$ & 2.5 & $\begin{array}{r}179 \\
24\end{array}$ & 7.5 \\
\hline Musculoskeletal diseases & $\begin{array}{l}\text { D } \\
\text { D } \\
\text { D/C }\end{array}$ & $\begin{array}{l}201 \\
113\end{array}$ & 1.8 & $\begin{array}{l}172 \\
104\end{array}$ & 1.7 & $\begin{array}{l}240 \\
130\end{array}$ & 1.8 & $\begin{array}{l}171 \\
122\end{array}$ & 1.4 \\
\hline
\end{tabular}

Notes $\mathrm{D}=$ Diabetics, $\mathrm{C}=$ Control, $\mathrm{D} / \mathrm{C}=$ Ratio of rate for diabetics/rate for control.

here for the sake of brevity. Exhaustive discussion of the pathogenetic and clinical management significance of these data is not possible in this brief paper. We intend to deal with it in depth in a more extensive paper which is currently in preparation.

\section{Conclusions}

The total study, from which the preceding data was extracted, aims to elucidate the other disease liabilities correlated with the existence of a salient, chronic condition. The main objective is to describe in a statistical way, as far as can be deduced from health services utilization patterns, the expanded pathogenetic history of a debilitating, chronic disease. The health services program planning possibilities of such an approach are enormous, provided that astute clinical management and services costing input is added to the epidemiological conceptualization. The possibilities of 
TABLE 8. Comparisons of Utilization, by Selected Health Problems (Patient Rate/1,000 Population)

\begin{tabular}{|c|c|c|c|c|c|c|}
\hline \multirow[b]{2}{*}{ Health Problems } & \multicolumn{3}{|c|}{ Outpatient } & \multicolumn{3}{|c|}{ Inpatient } \\
\hline & $\begin{array}{l}\text { Diabetic } \\
\text { Rate }\end{array}$ & $\begin{array}{l}\text { Control } \\
\text { Rate }\end{array}$ & $\begin{array}{l}\mathrm{D} / \mathrm{C} \\
\text { Ratio }\end{array}$ & $\begin{array}{l}\text { Diabetic } \\
\text { Rate }\end{array}$ & $\begin{array}{l}\text { Control } \\
\text { Rate }\end{array}$ & $\begin{array}{l}\mathrm{D} / \mathrm{C} \\
\text { Ratio }\end{array}$ \\
\hline Bacterial gastroenteritis & 75.4 & 42.4 & 1.8 & 22.0 & 25.1 & 0.9 \\
\hline $\mathrm{TB}$, respiratory, active & 40.8 & 7.9 & 5.2 & 47.1 & 23.6 & 2.0 \\
\hline Dermatophytosis, etc. & 47.1 & 15.7 & 3.0 & 14.1 & 9.4 & 1.5 \\
\hline Neoplasms, malignant & 6.3 & 1.6 & 4.0 & 14.1 & 3.1 & 4.5 \\
\hline Neoplasms, benign & 22.0 & 9.4 & 2.3 & 12.6 & 15.7 & 0.8 \\
\hline Obesity, not endocrine & 36.1 & 14.1 & 2.6 & 87.9 & 22.0 & 4.0 \\
\hline $\begin{array}{l}\text { Central \& peripheral } \\
\text { neurological diseases }\end{array}$ & 29.8 & 7.9 & 3.8 & 33.0 & 26.7 & 1.2 \\
\hline Cataract & 29.8 & 9.4 & 3.2 & 34.5 & 18.8 & 1.8 \\
\hline Essential benign hypertension & 202.5 & 56.5 & 3.6 & 97.3 & 44.0 & 2.2 \\
\hline Ischemic heart disease & 15.7 & 4.7 & 3.3 & 26.7 & 9.4 & 2.8 \\
\hline $\begin{array}{l}\text { Other heart \& Vascular } \\
\text { diseases }\end{array}$ & 108.3 & 50.2 & 2.2 & 11.0 & 64.4 & 1.7 \\
\hline Oral diseases & 37.7 & 11.0 & 3.4 & 34.5 & 17.3 & 2.0 \\
\hline $\begin{array}{l}\text { Diseases of esophagus \& } \\
\text { stomach }\end{array}$ & 44.0 & 28.3 & 1.6 & 86.4 & 36.1 & 2.4 \\
\hline Cirrhosis (hepatic) & 6.3 & 1.6 & 4.0 & 14.1 & 9.4 & 1.5 \\
\hline Cholelithiasis & 9.4 & 4.7 & 2.0 & 39.3 & 34.5 & 1.1 \\
\hline Symptoms ref. to GE tract & 56.5 & 22.0 & 2.6 & 34.5 & 17.3 & 2.0 \\
\hline Kidney infections & 22.0 & 1.6 & 13.8 & 47.1 & 26.7 & 1.8 \\
\hline Other urinary tract diseases & 222.9 & 62.8 & 3.5 & 87.9 & 45.5 & 1.9 \\
\hline Diseases, male genital tract & 14.1 & 1.6 & 8.8 & 26.7 & 9.4 & 2.8 \\
\hline Diseases, female genital tract & 42.4 & 12.6 & 3.4 & 51.8 & 25.1 & 2.1 \\
\hline Menstrual disorder, sterility & 20.4 & 14.1 & 1.4 & 22.0 & 4.7 & 4.7 \\
\hline Cellulitis & 45.5 & 28.3 & 1.6 & 86.4 & 25.1 & 3.4 \\
\hline Lymphadenitis, etc. & 17.3 & 7.9 & 2.2 & 11.0 & 1.6 & 6.9 \\
\hline Sebborrhea, eczema & 97.3 & 47.1 & 2.1 & 55.0 & 12.6 & 4.4 \\
\hline Rheumatoid, arthritis & 28.3 & 20.4 & 1.4 & 20.4 & 15.7 & 1.3 \\
\hline Osteoarthritis & 47.1 & 11.0 & 4.3 & 14.1 & 7.6 & 1.9 \\
\hline Osteomyelitis & 59.7 & 44.0 & 1.3 & 40.8 & 17.3 & 2.4 \\
\hline Dislocation, sprain & 40.8 & 15.7 & 2.2 & 20.4 & 17.3 & 1.2 \\
\hline Superficial injury, contusion & 65.9 & 45.5 & 1.4 & 40.8 & 36.1 & 1.1 \\
\hline Adverse effect, medical agent & 17.3 & 11.0 & 1.6 & 25.1 & 12.6 & 2.0 \\
\hline Normal delivery & - & - & - & 70.7 & 109.9 & 0.6 \\
\hline Complications, medical care & - & - & - & 29.8 & 4.7 & 6.3 \\
\hline
\end{tabular}

Notes: Outpatient rates $=$ number patients $/ 1,000$ population/annum, inpatient rates $=$ number patients $/ 1,000$ population/total period $(11 \mathrm{yrs}), \mathrm{D} / \mathrm{C}$ ratio $=$ rate for diabetics/rate for controls.

projection of expected workload, based upon trends in pathogenesis as well as changing demographic patterns, may lend validity to long-range planning. In extension of the study, we plan to explore the development of Bayesian correlation analyses of expected disease and severity grades thereof, based upon real data, to assist in clinical program review, as well as the development of clinical protocol for management of patients with regard to age, sex, and salient disease experience. This approach cuts across the customary organic systems and established program classifica- 
tions of public health planning; therefore, its implementation might meet with the obstacles of tradition. Nevertheless, it is an exciting kind of concept, aimed eventually at the planning of services for groups of people who share a pathologically correlated group of disease problems. From the standpoint of pathogenesis, as well as epidemiology, this approach appears to be eminently reasonable.

\section{Acknowledgments}

We are indebted to those of our colleagues who manage and operate the computerized health information system, for the data tabulations which formed the basis for our analyses. We are particu- larly grateful for the services of Mr. Peter Krauss, who programmed the outputs to fulfill our needs. Much of the extraction and assembly of data from the computer outputs was carried out by Mrs. Louise Burbank, who also typed the narrative and tables for this paper. Her contribution is acknowledged with sincere gratitude.

\section{References}

1. Bennett, Peter H.: Personal communication. Southwestern Field Station, National Institute Of Arthritis And Metabolic Disease, 1440 E. Indian School Road, Phoenix, Arizona 85014.

2. Reinhard, Karl R.: A systematic information approach to the planning of health care. Acta Socio-Medica Scandinavica, (Supp) 6, 162, 1972.

3. A recently revised form of the subject health problem taxonomy can be obtained by writing directly to the author. 